\title{
Knowledge about post-exposure proceedings of the operating block nurses
}

\author{
Wiedza o postępowaniu poekspozycyjnym pielęgniarek bloku operacyjnego
}

\section{Katarzyna Tomaszewska ${ }^{\oplus}$, Aleksandra Szpilla²}

'State Higher School of Technology and Economics in Jarosław/Państwowa Wyższa Szkoła Techniczno-Ekonomiczna w Jarosławiu ${ }^{2}$ Graduate of Collegium Masoviense - Higher School of Health Sciences in Żyrardów/ Absolwentka Collegium Masoviense - Wyższej Szkoły Nauk o Zdrowiu w Żyrardowie

\section{CORRESPONDING AUTHOR/AUTOR DO KORESPONDENCJ: \\ Katarzyna Tomaszewska \\ Państwowa Wyższa Szkoła Techniczno-Ekonomiczna, Instytut Ochrony Zdrowia ul. Czarnieckiego 16, 37-500 Jarosław e-mail: tomka8@wp.pl}

Wstęp. Występowanie ekspozycji zawodowej jest aktualnym problemem wśród personelu medycznego. Za grupę zawodową szczególnego ryzyka zakażenia drobnoustrojami chorobotwórczymi uznaje się pielęgniarki. Ważnym elementem profilaktyki jest podnoszenie wiedzy i świadomości pracowników w zakresie zagrożeń zawodowych i możliwości ich ograniczania. Edukacja personelu, znajomość metod zapobiegania zakażeniom, a także wiedza na temat bezpiecznych procedur, mogą zmniejszyć liczbę ekspozycji na materiał biologiczny lub w przypadku ich wystąpienia ograniczyć konsekwencje dla zdrowia.

Cel pracy. Celem badań była ocena wiedzy pielęgniarek zatrudnionych na bloku operacyjnym na temat postępowania poekspozycyjnego. Materiał i metody. Badania przeprowadzono po uzyskaniu zgody Komisji Bioetycznej na przełomie 2017 i 2018 roku w grupie 100 pielęgniarek operacyjnych. Do badań wykorzystano autorski kwestionariusz ankiety. Uzyskane wyniki zostały poddane analizie statystycznej, w której wykorzystano test U Manna-Whitneya, test Kruskala-Wallisa oraz korelację porządku rang Spearmana. W trakcie weryfikacji statystycznej zebranego materiału, za poziom istotności otrzymanych wyników przyjęto $p<0,05$.

Wyniki i wnioski. Badane pielęgniarki operacyjne posiadały wiedzę na temat postępowania poekspozycyjnego na dobrym poziomie (średnia ilość prawidłowych odpowiedzi w przeprowadzonym teście wiedzy wynosiła 14,41 na 18 możliwych, co stanowiło 80,06\% prawidłowych odpowiedzi). Poziom wiedzy badanych pielęgniarek nie był zależny od czynników takich jak: staż pracy, wykształcenie, wykształcenie podyplomowe, odbycie podczas okresu adaptacyjnego na bloku operacyjnym szkolenia dotyczącego przestrzegania procedur epidemiologicznych, praca na stanowisku, w którym jest wdrożona i przestrzegana procedura dotycząca ekspozycji zawodowej. Wiek badanych pielęgniarek istotnie wpływał na poziom ich wiedzy.

Słowa kluczowe: pielęgniarka operacyjna, ekspozycja zawodowa, postępowanie poekspozycyjne

\section{ABSTRACT} KNOWLEDGE ABOUT POST-EXPOSURE PROCEEDINGS OF THE OPERATING BLOCK NURSES

Introduction. Occurrence of occupational exposure is a current problem among medical personnel. Nurses are considered to be a special occupational group exposed to risk of infection with pathogenic microorganisms. An important element of prevention is raising the workers' knowledge and awareness in the field of occupational hazards and the possibilities of their reduction. Staff education, knowledge of infection prevention methods, and knowledge of safe procedures can reduce the number of exposures to biological material or, if they occur, limit the health consequences.

Aim. The aim of the research was to assess the knowledge of nurses employed on the operating block on the risk of occupational exposure and post-exposure proceedings.

Material and methods. The research after obtaining the consent of the Bioethical Commission was carried out at the turn of 2017 and 2018 in a group of 100 anesthesia nurses employed on operating blocks of two hospitals in the Podkarpackie Voivodeship. The author's questionnaire was used for the research. Obtained results were subjected to statistical analysis, in which the Mann-Whitney $\mathrm{U}$ test, the Kruskal-Wallis test and the correlation of Spearman's rank order were used. During the statistical verification of the collected material, $p<0.05$ was assumed as the level of significance of the obtained results.

Results and conclusions. The examined anesthesia nurses had knowledge about post-exposure procedures at a very good level (the average number of correct answers in the conducted test of knowledge was 14.41 out of 18 , which constituted $80.06 \%$ of correct answers). The level of knowledge of the examined nurses was not dependent on such factors as: seniority, education, postgraduate education, training during the adaptation period on the operating block, adherence to epidemiological procedures, work on the post in which the procedure for occupational exposure is implemented and followed. The age of the nurses significantly influenced their level of knowledge.

Key words: anesthesia nurse, occupational exposure, post-exposure proceedings 


\section{INTRODUCTION}

The problem of occupational risk for blood-borne infections of health care workers was noticed in 1949 in the United States, when a case of hepatitis was reported by one of the blood bank employees [1]. Occupational exposure is defined as the exposure of a worker to $\mathrm{HCV}$, HBV and HIV during his work. An exposed person is an employee who has been exposed to the risk of infection due to contact with potentially infectious biological material during his/her work [2]. Occupational groups which are subject to occupational exposure include, among others, nurses, physicians, matrons and medical students, as well as fire, police and other emergency services officers [3]. It has been demonstrated that among medical workers, nurses are the occupational group the most exposed to blood-borne infections. This results from their number as well as the nature and circumstances of work [4]. The material causing the infection can basically be any biological material which contains the pathological pathogen in the amount necessary for infection [5]. The potentially infectious material may also include vaginal discharge, semen, peritoneal fluid, pleural, smear, breast milk, foetal waters or other body fluid, especially if it contains blood. The risk of infection in case of contact with the above-mentioned materials is much lower than with blood. There is a negligible risk of infection in case of contact with urine, faeces, vomiting, sweat, tears and nasal discharge. The main cause of infections is the failure of medical personnel to comply with health and safety rules.

The risk of occupational exposure is lower if the facility employing an employee has modern equipment, e.g.: the so-called safe equipment, protecting against accidental stabbing and equipment which is made of materials protecting against the transmission of viruses [6]. During procedures which require the interruption of continuity of tissues, safety is ensured by meeting the appropriate conditions: knowledge, protective measures, adherence to the principles of prophylaxis, planning of the procedure and assessment of possible consequences [7]. The prevention activities of occupational exposure of medical personnel are described in legal regulations, e.g.: The Labour Code, Constitution of the Republic of Poland, National Health Programme, Directive of the European Union of May 10, 2010 and the Regulation of the Minister of Health on occupational safety and health during work related to the risk of sharps injuries, which are used during health care services of June 6, 2013 [8].

In Poland, the recommended post-exposure scheme is consistent with the guidelines of Centers for Disease Control and Prevention. According to these guidelines, the employer must ensure that an employee who has been exposed is able to contact a doctor for infectious diseases around the clock. In addition, every workplace where an event may occur must have a stock of hepatitis B vaccines and antiretroviral drugs to be given to the worker as soon as possible after exposure [9]. Post-exposure measures should be implemented immediately after the event, thus reducing the risk of virus infection [10]. The exposed worker should apply the so-called non-specific prophylaxis immediately after the exposure, which includes the proper management of the exposed site as well as formal and legal aspects [11].

Despite the procedures in place and standards implemented in health care units, occupational exposure still occurs particularly among nursing staff. The aim of the study was to assess the knowledge of surgical nurses about post-exposure procedures.

\section{MATERIALS AND METHODS}

The study was conducted in the period from November 1 , 2017 to January 12, 2018 in the group of 100 surgical nurses employed in the operating blocks of two hospitals in the Podkarpackie Voivodeship. The research was carried out using a proprietary questionnaire consisting of 24 questions. The obtained results were subject to statistical analysis. Prior to the analysis, the database was checked for logic and completeness of answers. Then, the statistical package Statistica v.13.1 PL of StatSoft, Inc. was used for the calculations. Mann-Whitney's U test was used to compare two tested groups in terms of orderly characteristics, which is the most suitable for comparison of variables of orderly or quantitative nature that do not meet the condition of normal distribution in two independent groups. The Kruskal-Wallis test was used to compare at least three of the studied groups in terms of their ordinal characteristics, which is the most suitable for the comparison of variables of an ordinal or quantitative nature that do not meet the condition of normal distribution in more than two independent groups. Spearman's rank order correlation was used to investigate the relationship between the ordinal variables, which is the most suitable method to study the correlation between two ordinal or quantitative variables that do not meet the condition of normal distribution (regardless of the number of groups). During the statistical verification of the collected material, $\mathrm{p}<0.05$ was taken as the level of significance of the obtained results. The value of the analyzed non-measurable parameters was presented by means of percentage distribution, while those measured by means of descriptive statistics.

\section{RESULTS}

The survey was conducted on a group of 100 surgical nurses, of which the most numerous group were respondents in the age range of $40-50$ years (37\%), while in the age range of $20-30$ years $-27 \%, 30-40$ years old $-22 \%$. The least numerous group were nurses over $50-14 \%$. Due to the length of service, the examined group is divided quite equally. About every fourth surgical nurse has worked in the profession for 21-30 years (27\%), every fourth 11-20 years (26\%), and every fifth one $-0-5$ years $(21 \%)$, respectively. Nurses with 6-10 years of service consisted of $16 \%$. On the other hand, the smallest share in the group were instrumental nurses working in the profession for over 30 years (10\%). In terms of education, the surveyed surgical nurses are divided relatively equally. When it comes to $29 \%$ of the study group, they consisted of certified nurses (completed high school or nursing studies), 36\% Bachelor of Nursing, 35\% 
Master of Nursing. Almost half of the surveyed surgical nurses (47\%) has a qualification course in surgical nursing, while almost as many of them are specialists in this field (37\%). When it comes to $7 \%$ of the respondents, they declared that they have post-graduate education in another field of nursing. The vast majority of the surveyed surgical nurses $(84 \%)$ received training in observing epidemiological procedures during the adaptation period in the surgical block. The percentage of nurses who responded negatively was only $16 \%$. The majority of surgical nurses (86\%) claimed that the procedure concerning occupational exposure is implemented and observed at their workplace, only $14 \%$ of the surveyed nurses answered partially, while none of them answered negatively.

The standard deviations of the level of knowledge of the nurses under investigation due to age ranged from 1.78 to 2.56 (Figure 1 ).

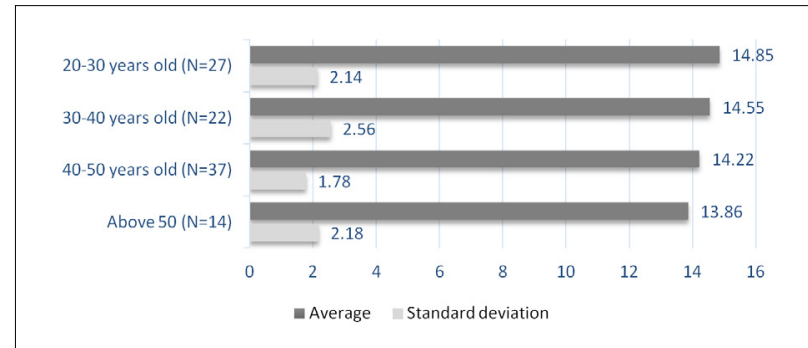

Fig 1. Level of knowledge on post-exposure behavior by age of respondents (basic descriptive statistics)

The above results indicate that with age, the level of knowledge about post-exposure proceedings decreased. The differences between individual age groups were significant, which is also confirmed by the results of correlation of Spearman's rank order. According to Spearman's rank order, age statistically significantly $(\mathrm{p}<0.05)$ differentiated the level of knowledge of the examined surgical nurses about post-exposure management. Younger nurses showed greater knowledge in this respect than older ones.

The examined surgical nurses answered correctly to 14.41 questions out of 18 checking the knowledge about post-exposure management (the smallest number of correct answers was 8 and the largest number was 18). The median for the set of answers was 15, standard deviation 2.12 (Figure 2). Nearly all the respondents know how to proceed in case of tissue discontinuity violation due to: punctures, cuts, scratches with a medical tool contaminated with blood (92\%) (Figure 3). The questions about how to proceed were slightly worse. As many as $86 \%$ of respondents know what kind of tests are performed in an exposed person (Figure 4).

Moreover, the level of knowledge of the respondents on post-exposure procedures did not depend on the work of the respondents in the position where the occupational exposure procedure is implemented and followed. Nurses who worked in such a position gave slightly more correct answers (14.60 on average) than those who did not receive such training (13.21 respectively). Any differences between the two groups were not significant. This is also confirmed by the results of the U Mann-Whitney test, according to which, the work in the position where the occupational exposure procedure is implemented and followed did not have a statistically significant impact ( $p>0.05)$ on the level of knowledge of the respondents about post-exposure procedures (Table 1).

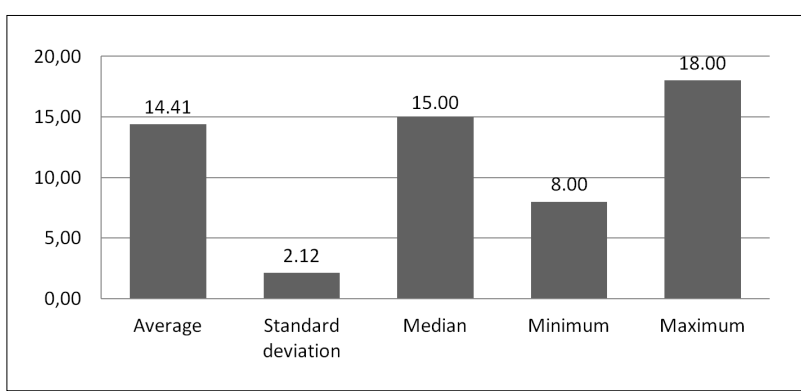

Fig 2. Level of knowledge of post-exposure proceedings (basic descriptive statistics)

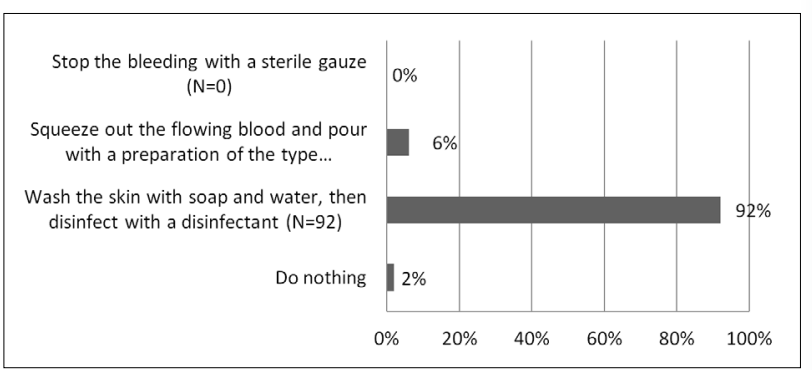

- Fig 3. Knowledge on the subjects of the activities to be performed in the situation of tissue violation as a result of punctures, cuts, scratches with a medical tool contaminated with blood

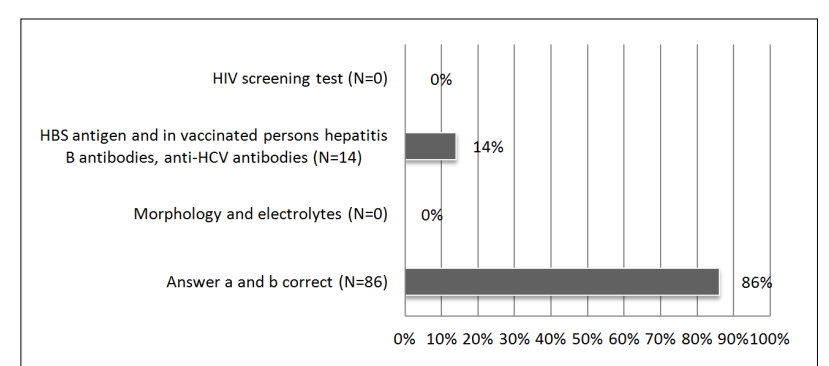

Fig 4. Knowledge of the subjects about the tests performed on the exposed person

Tab. 1. Relationship between the work of the respondents in the position in which the occupational exposure procedure is both implemented and observed, and the level of knowledge about post-exposure behavior

\begin{tabular}{|c|c|c|c|c|}
\hline & \multicolumn{2}{|c|}{$\begin{array}{l}\text { Work in a position in which the } \\
\text { occupational exposure procedure } \\
\text { is implemented and followed }\end{array}$} & \multirow{2}{*}{$\begin{array}{l}\text { The results } \\
\text { of the } \\
\text { U Mann- } \\
\text { Whitney test }\end{array}$} \\
\hline & & Yes $(\mathrm{N}=86)$ & $\begin{array}{c}\text { Only partially } \\
(\mathrm{N}=14)\end{array}$ & \\
\hline \multicolumn{2}{|l|}{ Average } & 14.60 & 13.21 & \multirow{8}{*}{$\begin{array}{l}Z=1.823 \\
p=0.068\end{array}$} \\
\hline \multicolumn{2}{|c|}{ Standard deviation } & 1.94 & 2.78 & \\
\hline \multirow{2}{*}{$\begin{array}{l}\text { Confidence } \\
\text { level }\end{array}$} & $-95.00 \%$ & 14.19 & 11.61 & \\
\hline & $+95.00 \%$ & 15.02 & 14.82 & \\
\hline \multicolumn{2}{|l|}{ Median } & 15.00 & 13.00 & \\
\hline \multicolumn{2}{|l|}{ Minimum } & 8.00 & 9.00 & \\
\hline \multicolumn{2}{|l|}{ Maximum } & 18.00 & 18.00 & \\
\hline \multicolumn{2}{|c|}{ Standard error } & 0.21 & 0.74 & \\
\hline
\end{tabular}

$z$ - test value; $p$ - significance level for the above test value. 


\section{DISCUSSION}

Health professionals are particularly exposed to biological harmful factors due to the specific nature of their profession. Significant occupational risks are mainly due to infections via blood derivatives during the procedures related to blood collection and surgical procedures [12]. Szczypta, Różańska and Bulanda in their studies demonstrated that the highest incidences of exposure were reported among nurses; the mean percentage of events in the analysed period for this occupational group was $67.8 \%$. Among physicians it was $29.7 \%$ and the lowest among other workers - 1.5\% [13]. The subject of exposure is discussed in many publications. Very often attempts were made to determine the scale of the problem. The analysis of data on haematopoietic exposures among the employees of a surgical hospital with 130 beds shows that 18 persons were exposed to occupational therapy annually [14]. The list created from reports delivered from 61 facilities located in the Wielkopolskie Voivodeship presents the number of reported exposures. It shows that in the years 2009-2011, 1834 health care workers were exposed, 1185 of them were nurses [15]. The study by Garus-Pakowska and Szatko showed that only 18.9\% of nurses has never experienced occupational exposure during their professional duties. The fact that only $67.7 \%$ of the nurses exposed reported the event to their supervisor may be a cause for concern [16]. It may be puzzling whether this phenomenon is connected with the lack of knowledge about post-exposure proceedings. During the analysis of literature, the research concerning the level of nurses' knowledge about the post-exposure proceedings was not reached. In the study by Braczkowska et al., the vast majority of exposed medical workers were women (n $=613 ; 78.9 \%$ ). This results from the professional profile of medical workers - the most exposed professional group were nurses (65\%) [17]. In order to increase occupational safety, it is important for employers to provide multi-faceted education on occupational exposure prevention [7]. Our own research shows that almost every surgical nurse (84\% of respondents) in the adaptation period received training on observing the epidemiological procedures and that most of them work in a position where the post-exposure procedure is implemented and observed (86\%). This does not fully coincide with Dyk-Duszyńska's research conducted among nurses working in hospitals, outpatient clinics and other health care institutions, both of surgical and non-surgical profile. Only $64.81 \%$ of nurses declared that they participated at least once in the training on occupational exposure prevention [15].

Garus-Pakowska and Szatko [16] found that 98.2\% of nurses had contact with blood or other body fluids at least several times a week (77.5\% of physicians). In this group, $82.9 \%$ of nurses and $60 \%$ of physicians have such contacts even several times a day. At the same time, nurses are significantly more frequently injured accidentally by contaminated medical instruments than doctors $(\mathrm{p}=0.011)$. The study also confirmed that the staff of surgical wards has more frequent contact with blood and other body fluids on a daily basis than the staff of conservative wards $(p=0.009)$. The risk of percutaneous exposure increases with the length of service. Every third employee with up to 15 years' seniority compared to only every fifth employee working for more than 15 years has never been injured in the course of his professional duties $(p=0.001)$. Szczypta, Różanska and Bulanda in their research showed that the highest average exposure rate was found in the operating block - it was $11.8 \%$. Average exposure rates in the surgical wards ranged from 7.5 to $9.2 \%$ and were about 2 times higher than the corresponding figure for the Internal Medicine Ward (4.4\%). The highest number of cases of exposure was recorded among nurses - the average percentage of events in the analyzed period for this professional group was $67.8 \%$, then among physicians $(29.7 \%)$ and the lowest among other workers (1.5\%). More than $90 \%$ of cases of reported exposures in the whole analyzed period were either evident $(88.1 \%)$ or probable $(4.5 \%)$. On average, about $7 \%$ were exposures in which the doctor, to whom the employee reported the exposure, did not assess the probability of infectivity of the material or which concerned contact with undamaged skin. Only in $0.18 \%$ of cases the exposure was questionable [14]. Despite the wide possibilities of occupational exposure prevention, it cannot be completely eliminated [15]. In the case of exposure to potentially infectious material, the worker should implement post-exposure procedures as soon as possible. The actions taken are aimed at reducing the risk of infection with the pathogenic microorganism [18]. According to the study carried out by Dyk-Duszyńska, the knowledge of post-exposure procedure is declared by almost all nurses $(90.42 \%)$. Our study demonstrated that the knowledge about post-exposure procedures of surgical nurses is high. These nurses gave an average of 14.41 correct answers to 18 questions in the conducted test, which is $80.6 \%$. Immediately after exposure, non-specific procedures should be implemented as soon as possible, which depends on the type of exposure [15]. In this case, surgical nurses showed very high level of knowledge. Almost every instrumentalist knows what actions to take in case of splashing of mucous membranes or ocular mucous membranes (99\%). Nearly all of the examined women also know what to do in the case of tissue continuity violation as a result of: pricks, cuts, scratches with a medical tool contaminated with blood (92\%) and blood entering the mouth (98\%). Slightly worse were the questions concerning further procedure. As many as $86 \%$ of respondents know what tests are performed in an exposed person. When it comes to $88 \%$ of nurses, they knew when the anti-HCV antibody test was performed, while only $46 \%$ knew that anti-HIV antibody tests are performed immediately after exposure and then periodically for the next 6 months (e.g. after 6 weeks, 12 weeks and the last 6 months).

Nurses working in the operating theatre have a diverse education. However, statistical analysis showed that this does not affect their level of knowledge about post-exposure procedures. The experience, training on the observance of epidemiological procedures during the adaptation period in the operating theatre, working in a position where the occupational exposure procedure is implemented and observed are also irrelevant. Indeed, only statisti- 
cal age differentiates surgical nurses. The younger ones showed a slightly higher level of knowledge. The studies by Garus-Pakowska and Szatko also show that more frequent incidents of exposure occur at nurses with more experience [16].

It is considered essential to improve occupational safety of health care personnel in contact with blood and other potentially infectious material, if proper multi-faceted education is to be provided, which should include such issues as: proper rules of handling medical equipment, medical waste, training in post-exposure prophylaxis standards, use of personal protective equipment, as well as the required preventive vaccinations for personnel, and development of educational programmes for medical workers [17].

Employees of the medical sector, due to their profession, are a group at particular risk of infection, which is why detailed legal regulations have been introduced in Poland, specifying the obligations of employers of the health care sector in terms of occupational health and safety when performing work related to exposure to sharps used in the provision of health care services. It seems justified to constantly supplement the knowledge of medical personnel in this area.

\section{CONCLUSIONS}

1. The level of knowledge of surgical nurses about post-exposure procedures is high and professional experience does not differentiate surgical nurses in terms of knowledge about post-exposure procedures.

2. The age of the respondents differentiates them in terms of knowledge about post-exposure proceedings - older nurses have significantly lower level of knowledge.

3. The education of surgical nurses does not differentiate them in terms of knowledge about post-exposure management. Surgical nurses who have received training in epidemiological procedures at their workplace do not have a higher level of knowledge in this field.

\section{Wiedza o postępowaniu poekspozycyjnym pielęgniarek bloku operacyjnego}

\section{WPROWADZENIE}

Problem ryzyka zawodowego na zakażenia krwiopochodne, pracowników służby zdrowia został zauważony w 1949 roku w Stanach Zjednoczonych, kiedy to zgłoszono przypadek zapalenia wątroby u jednego $\mathrm{z}$ pracowników banku krwi [1]. Ekspozycję zawodową definiuje się jako narażenie na zakażenie pracownika wirusami $\mathrm{HCV}$, HBV oraz HIV, podczas wykonywania pracy zawodowej. Osoba eksponowana to pracownik, który w trakcie wykonywania służbowych obowiązków został narażony na ryzyko zakażenia na skutek kontaktu z biologicznym materiałem potencjalnie zakaźnym [2]. Grupy zawodowe, których dotyczy ekspozycja zawodowa to m.in. pielęgniarki, lekarze, salowe, studenci kierunków medycznych, a także funkcjonariusze straży pożarnej, policji oraz pozostałych służb ratowniczych [3]. Dowiedziono, że spośród pracowników medycznych najbardziej narażoną na zakażenia krwiopochodne grupą zawodową są pielęgniarki. Wynika to, zarówno z ich liczebności jak i charakteru i okoliczności wykonywanej pracy [4]. Materiałem powodującym zakażenie może być w zasadzie każdy biologiczny materiał, który zawiera patologiczny patogen w niezbędnej ilości do zakażenia [5]. Materiałem potencjalnie zakaźnym może być również: wydzielina pochwowa, nasienie, płyn otrzewnowy, opłucnowy, maziowy, mleko kobiece, wody płodowe lub inny ustrojowy płyn zwłaszcza jeśli zawiera krew. Ryzyko zakażenia w przypadku kontaktu z powyżej wymienionymi materiałami jest znacznie mniejsze niż z krwią. Znikome ryzyko zakażenia występuje w przypadku kontaktu z moczem, kałem, wymiocinami, potem, łzami i wydzieliną z nosa. Przyczyną zakażeń jest głównie nieprzestrzeganie przez personel medyczny zasad bezpieczeństwa oraz higieny pracy.
Ryzyko ekspozycji zawodowej jest mniejsze jeżeli placówka zatrudniająca pracownika posiada nowoczesne wyposażenie np.: tzw. bezpieczny sprzęt, chroniący przed przypadkowym zakłuciem oraz sprzęt, który jest wykonany z materiałów zabezpieczających przed transmisją wirusów [6]. Podczas wykonywania zabiegów, które wymagają przerwania ciągłości tkanek, bezpieczeństwo zapewnia spełnianie przez pracowników właściwych warunków: posiadanie wiedzy, zastosowanie środków ochrony, przestrzeganie zasad profilaktyki, zaplanowanie zabiegu oraz ocenianie możliwych następstw [7]. O działaniach prewencyjnych ekspozycji zawodowej u personelu medycznego mówią przepisy prawne m.in.: Kodeks pracy, Konstytucja RP, Narodowy Program Zdrowia, Dyrektywa Unii Europejskiej z dnia 10 maja 2010 roku oraz Rozporządzenie Ministra Zdrowia w sprawie bezpieczeństwa i higieny pracy podczas wykonywania prac związanych z ryzykiem zranienia ostrymi narzędziami, które są używane podczas udzielania świadczeń zdrowotnych $\mathrm{z}$ dnia 6 czerwca 2013 roku [8].

W Polsce zalecany schemat postępowania po wystapieniu ekspozycji jest zgodny z wytycznymi Centers for Disease Control and Prevention (Centrum Zwalczania i Zapobiegania Chorobom). Według tych wskazówek pracodawca musi zapewnić pracownikowi, który został eksponowany całodobową możliwość kontaktu z lekarzem chorób zakaźnych. Co więcej, w każdym zakładzie pracy, w którym może dojść do zdarzenia musi być zapas szczepionek przeciwko WZW typu B oraz leków antyretrowirusowych, aby mogły zostać podane pracownikowi jak najszybciej po ekspozycji [9]. Postępowanie poekspozycyjne powinno zostać wdrożone bezpośrednio po zdarzeniu, 
zmniejsza to ryzyko zakażenia wirusem [10]. Eksponowany pracownik bezpośrednio po wystąpieniu ekspozycji powinien zastosować tzw. profilaktykę nieswoistą, która obejmuje właściwe postępowanie $\mathrm{z}$ miejscem eksponowanym a także, aspekty formalno-prawne [11].

Pomimo obowiązujących procedur i wdrożonych standardów w jednostkach ochrony zdrowia ekspozycje zawodowe nadal mają miejsce szczególnie wśród personelu pielęgniarskiego. Celem badań była ocena stanu wiedzy pielęgniarek operacyjnych na temat postępowania poekspozycyjnego.

\section{MATERIAŁ I METODY}

Badania przeprowadzono w okresie od 1 listopada 2017 r. do 12 stycznia 2018 r. w grupie 100 pielęgniarek operacyjnych zatrudnionych na blokach operacyjnych dwóch szpitali w województwie podkarpackim. Do badań wykorzystano autorski kwestionariusz ankiety składający się z 24 pytań. Uzyskane wyniki zostały poddane analizie statystycznej. Przed przystąpieniem do analizy baza danych została sprawdzona pod względem logiczności i kompletności odpowiedzi. Natomiast w dalszej kolejności, do wykonania obliczeń wykorzystany został pakiet statystyczny Statistica v.13.1 PL firmy StatSoft, Inc. Do porównania dwóch badanych grup pod względem cech porządkowych wykorzystano test U Manna-Whitneya, będący najodpowiedniejszy dla porównania zmiennych o charakterze porządkowym lub ilościowym niespełniających warunku normalności rozkładu w dwóch niezależnych grupach. Do porównania minimum trzech badanych grup pod względem cech porządkowych wykorzystano test Kruskala-Wallisa, będący najodpowiedniejszy dla porównania zmiennych o charakterze porządkowym lub ilościowym niespełniających warunku normalności rozkładu w więcej niż dwóch niezależnych grupach. Do zbadania związku pomiędzy zmiennymi o charakterze porządkowym wykorzystano korelację porządku rang Spearmana, będącą najodpowiedniejszą metodą do badania współzależności między dwoma zmiennymi o charakterze porządkowym lub ilościowym niespełniających warunku normalności rozkładu (bez względu na liczbę grup). W trakcie weryfikacji statystycznej zebranego materiału, za poziom istotności otrzymanych wyników przyjęto $\mathrm{p}<0,05$. Wartość analizowanych parametrów niemierzalnych przedstawiono przy pomocy rozkładu procentowego, zaś mierzalnych przy pomocy statystyk opisowych.

\section{WYNIKI}

Badanie ankietowe zostało przeprowadzone na grupie 100 pielęgniarek operacyjnych z czego najliczniejszą grupę stanowiły respondentki w przedziale wiekowym 40-50 lat (37\%), natomiast w wieku 20-30 lat odpowiednio 27\%, od 30-40 lat -22\%. Najmniej liczną grupę stanowiły pielęgniarki powyżej 50 roku życia 14\%. Ze względu na staż pracy badana grupa podzielona jest dość równo. Około co czwarta pielęgniarka operacyjna pracuje w zawodzie 21-30 lat (27\%), odpowiednio - co czwarta 11-20 lat
(26\%), i co około czwarta - odpowiednio 0-5 lat (21\%). Niewiele mniej zbadanych było pielęgniarek ze stażem pracy 6-10 lat (16\%). Natomiast najmniejszy udział w grupie stanowiły instrumentariuszki pracujące w zawodzie powyżej 30 lat (10\%). Pod względem wykształcenia badane pielęgniarki operacyjne podzielone są stosunkowo równo. $29 \%$ w badaniu stanowiły pielęgniarki dyplomowane (ukończone liceum bądź studium pielęgniarskie), $36 \%$ licencjat pielęgniarstwa, 35\% magister pielęgniarstwa. Prawie połowa badanych pielęgniarek operacyjnych (47\%) posiada kurs kwalifikacyjny w dziedzinie pielęgniarstwa operacyjnego, natomiast prawie tyle samo z nich jest specjalistkami w tej dziedzinie (37\%). $7 \%$ respondentek zdeklarowało, że posiada wykształcenie podyplomowe w innej dziedzinie pielęgniarstwa. Zdecydowana większość badanych pielęgniarek operacyjnych (84\%) odbyła podczas okresu adaptacyjnego w bloku operacyjnym szkolenie dotyczące przestrzegania procedur epidemiologicznych. Odsetek pielęgniarek, które odpowiedziały przecząco wyniósł jedynie $16 \%$. Większość pielęgniarek operacyjnych (86\%) twierdzi, że na ich stanowisku pracy jest wdrożona i przestrzegana procedura dotycząca ekspozycji zawodowej, tylko $14 \%$ badanych odpowiedziało, że częściowo, natomiast żadna $\mathrm{z}$ nich nie odpowiedziała przecząco.

Średnie arytmetyczne $(\bar{x})$ oraz odchylenia standardowe (SD) poziomu wiedzy badanych pielęgniarek ze względu na wiek oscylowały na $(\overline{\mathrm{x}})$ od 13,86 do 14,85 oraz (SD) od 1,78 do 2,56 (Ryc. 1).

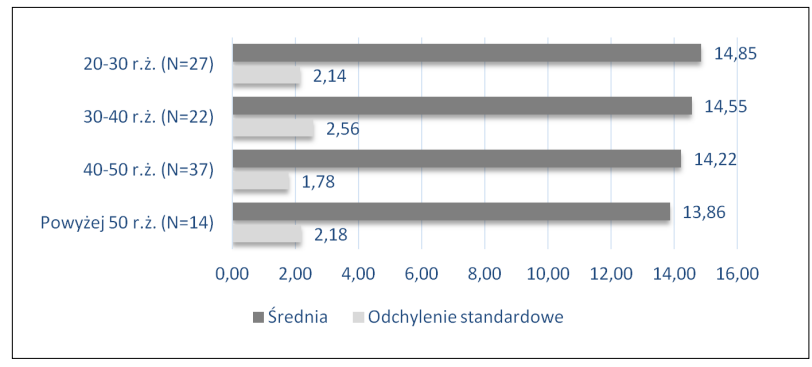

Ryc 1. Poziom wiedzy na temat postępowania poekspozycyjnego w podziale na wiek badanych (podstawowe statystyki opisowe)

Legenda: średnia arytmetyczna (x); odchylenie standardowe (SD)

Powyższe wyniki wskazują, że wraz z wiekiem malał poziom wiedzy badanych na temat postępowania poekspozycyjnego. Różnice między poszczególnymi grupami wiekowymi były znaczące, co potwierdzają również wyniki korelacji porządku rang Spearmana. Zgodnie z nimi, wiek był czynnikiem istotnym statystycznie $(\mathrm{p}<0,05)$ różnicował poziom wiedzy badanych pielęgniarek operacyjnych na temat postępowania poekspozycyjnego. Młodsze pielęgniarki wykazywały się większą wiedzą w tym zakresie niż te starsze.

Badane pielęgniarki operacyjne odpowiedziały prawidłowo na $\overline{\mathrm{X}}=14,41$ pytań $\mathrm{z} 18$ sprawdzających wiedzę na temat postępowania poekspozycyjnego (najmniejsza liczba prawidłowych odpowiedzi to 8, zaś największa 18). Mediana dla zbioru odpowiedzi wyniosła 15, odchylenie standardowe 2,12 (Ryc. 2).

Prawie wszystkie badane wiedzą także jak postąpić w przypadku naruszenia ciągłości tkanek w wyniku: zakłucia, skaleczenia, zadrapania narzędziem medycznym skażonym krwią (92\%) (Ryc. 3). 
Nieznacznie gorzej wypadły pytania dotyczące dalszego postępowania. $86 \%$ badanych wie jakie badania wykonuje się u osoby eksponowanej (Ryc. 4).

Ponadto, poziom wiedzy badanych na temat postępowania poekspozycyjnego nie zależał od pracy badanych

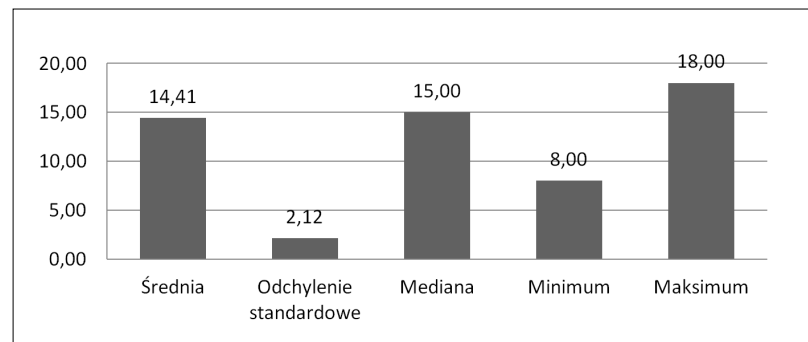

Ryc 2. Poziom wiedzy badanych na temat postępowania poekspozycyjnego (podstawowe statystyki opisowe)

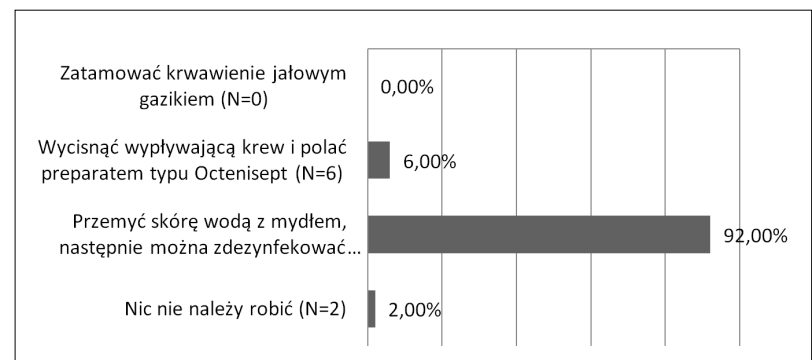

$0,00 \% \quad 20,00 \% \quad 40,00 \% 60,00 \% 80,00 \% 100,00 \%$

Ryc 3. Wiedza badanych na temat czynności, jakie należy wykonać w sytuacj naruszenia ciągłości tkanek w wyniku: zakłucia, skaleczenia, zadrapania narzędziem medycznym skażonym krwią

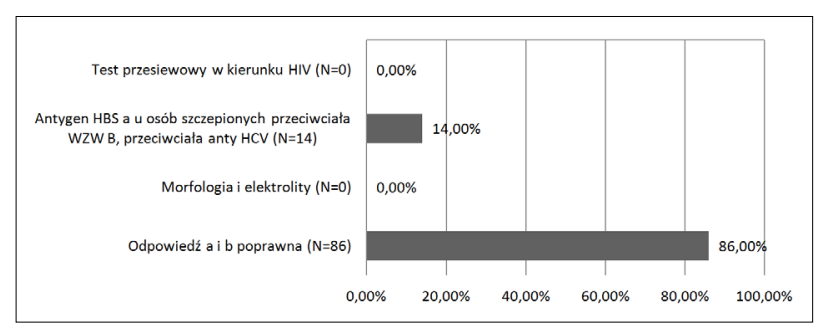

Ryc 4. Wiedza badanych na temat badań wykonywanych u osoby eksponowanej

Tab. 1. Zależność między pracą badanych na stanowisku, w którym jest wdrożona i przestrzegana procedura dotycząca ekspozycji zawodowej a poziomem wiedzy na temat postępowania poekspozycyjnego

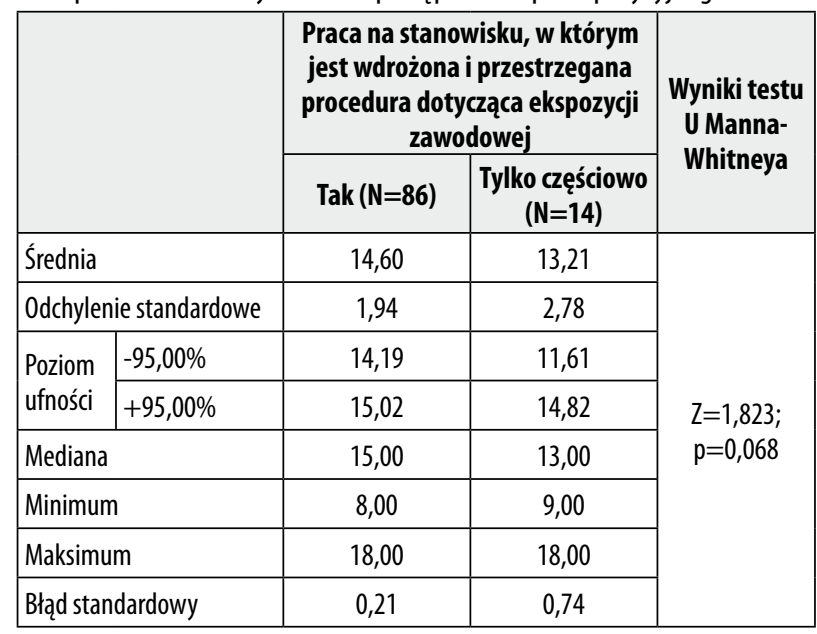

$\mathrm{z}$ - wartość testu; $\mathrm{p}$ - poziom istotności dla powyższej wartości testu. na stanowisku, w którym jest wdrożona i przestrzegana procedura dotycząca ekspozycji zawodowej. Pielęgniarki, które pracowały na takim stanowisku udzieliły nieco więcej prawidłowych odpowiedzi (średnio $\overline{\mathrm{x}}=14,60$ ) niż te, które nie odbyły takiego szkolenia (odpowiednio $\overline{\mathrm{x}}=13,21$ ). Jakiekolwiek różnice między obiema grupami nie były znaczące. Potwierdzają to również wyniki testu U Manna-Whitneya, zgodnie z którymi praca na stanowisku, w którym jest wdrożona i przestrzegana procedura dotycząca ekspozycji zawodowej nie wpływała istotnie statystycznie $(p>0,05)$ na poziom wiedzy badanych na temat postępowania poekspozycyjnego (tabela 1).

\section{DYSKUSJA}

Ze względu na specyfikę wykonywanego zawodu osoby pracujące w służbie zdrowia są szczególnie narażone na kontakt $\mathrm{z}$ biologicznymi czynnikami szkodliwymi. Znaczące ryzyko zawodowe stanowią przede wszystkim zakażenia na drodze krwiopochodnej podczas wykonywania procedur zabiegowych związanych z pobieraniem krwi jak i zabiegów operacyjnych [12]. Szczypta, Różańska i Bulanda w swoich badaniach dowiodły, że najwięcej przypadków ekspozycji odnotowano wśród pielęgniarek - średni odsetek zdarzeń w analizowanym okresie dla tej grupy zawodowej wyniósł 67,8\%. Wśród lekarzy wynosił on $29,7 \%$, a najmniejszy był wśród pozostałych pracowników - 1,5\% [13]. Temat ekspozycji jest poruszany w wielu publikacjach. Bardzo często próbowano określić skalę problemu. Z analizy danych o krwiopochodnych ekspozycjach zawodowych wśród pracowników szpitala zabiegowego liczącego 130 łóżek wynika że, rocznie ekspozycji zawodowej ulegało 18 osób [14]. Zestawienie stworzone z raportów dostarczonych z 61 placówek znajdujących się w województwie Wielkopolskim przedstawia ilość zgłoszonych ekspozycji. Wynika z niego, że w latach 20092011 doszło do 1834 ekspozycji pracowników służby zdrowia z czego 1185 stanowiły pielęgniarki [15]. Badania Garus-Pakowskiej i Szatko wykazały, że tylko 18,9\% pielęgniarek podczas wykonywania obowiązków zawodowych nigdy nie doświadczyło ekspozycji zawodowej. Zaniepokojenie może budzić fakt, iż jedynie 67,7 \% eksponowanych pielęgniarek zgłasza zaistniałe zdarzenie przełożonemu [16]. Zastanawiać może fakt czy zjawisko to związane jest $\mathrm{z}$ brakiem wiedzy na temat postępowania poekspozycyjnego. Podczas analizy piśmiennictwa nie dotarto do badań dotyczących poziomu wiedzy pielęgniarek na temat postępowania po zdarzeniu. W badaniach Braczkowskiej i wsp. wśród eksponowanych pracowników medycznych zdecydowaną większość stanowiły kobiety ( $\mathrm{n}=613 ; 78,9 \%$ ). Wynika to m.in. $\mathrm{z}$ profilu zawodowego pracowników medycznych - najczęściej eksponowaną grupą zawodową były pielęgniarki (65\%) [17]. W celu zwiększenia bezpieczeństwa pracy, istotnym jest prowadzenie przez pracodawców wieloaspektowej edukacji dotyczącej prewencji ekspozycji zawodowej [7]. Z badań własnych wynika że, prawie każda pielęgniarka operacyjna (84\% badanych) w okresie adaptacyjnym odbyła szkolenie dotyczące przestrzegania procedur epidemiologicznych oraz, że większość z nich pracuje na stanowisku, gdzie 
procedura dotycząca postępowania poekspozycyjnego jest wdrożona oraz przestrzegana (86\%). Nie do końca pokrywa się to z badaniami Dyk-Duszyńskiej przeprowadzonymi wśród pielęgniarek pracujących w szpitalach, poradniach i innych placówkach służby zdrowia, zarówno o profilu zabiegowym jak i niezabiegowym. Tylko $64,81 \%$ pielęgniarek zdeklarowało że choć raz brało udział w szkoleniu na temat profilaktyki ekspozycji zawodowej [15].

Garus-Pakowska i Szatko [16] w swoich badaniach stwierdzili, że wśród pielęgniarek 98,2\% ma kontakt z krwią lub innymi płynami ustrojowymi co najmniej kilka razy w tygodniu (w grupie lekarzy odsetek ten wyniósł 77,5\%). W tym $82,9 \%$ pielęgniarek oraz $60 \%$ lekarzy ma takie kontakty do nawet kilkunastu razy dziennie. Jednocześnie pielęgniarki istotnie częściej niż lekarze ulegają przypadkowym zranieniom zanieczyszczonymi narzędziami medycznymi $(\mathrm{p}=0,011)$. W badaniu potwierdzono także, że personel oddziałów zabiegowych ma na co dzień częstszy kontakt z krwią i innymi płynami ustrojowymi niż personel oddziałów zachowawczych $(\mathrm{p}=0,009)$. Ryzyko ekspozycji przezskórnej wzrasta natomiast wraz z wydłużaniem się stażu pracy. Co trzeci pracownik o stażu do 15 lat w porównaniu do już tylko co piątego pracującego dłużej niż 15 lat nigdy nie uległ zranieniu w trakcie wykonywania obowiązków zawodowych ( $\mathrm{p}=0,001)$. Szczypta, Różańska i Bulanda w swoich badaniach wykazali, że najwyższy średni współczynnik ekspozycji stwierdzono na Bloku Operacyjnym - wynosił on $11,8 \%$. Średnie wartości współczynników ekspozycji na oddziałach zabiegowych mieściły się w przedziale 7,5-9,2\% i tym samym były około 2-krotnie wyższe niż analogiczna wartość dla Oddziału Chorób Wewnętrznych $(4,4 \%)$. Najwięcej przypadków ekspozycji odnotowano wśród pielęgniarek - średni odsetek zdarzeń w analizowanym okresie dla tej grupy zawodowej wyniósł 67,8\%), następnie wśród lekarzy $(29,7 \%)$, a najmniej wśród pozostałych pracowników (1,5\%). Ponad $90 \%$ przypadków zgłoszonych ekspozycji w całym analizowanym okresie to ekspozycje ewidentne $(88,1 \%)$ lub prawdopodobne $(4,5 \%)$. Średnio około 7\% stanowiły ekspozycje, w których lekarz, do którego zgłaszał się pracownik w przypadku ekspozycji, nie ocenił prawdopodobieństwa zakaźności materiału, lub które dotyczyły kontaktu z nieuszkodzoną skórą. Tylko w 0,18\% przypadków ekspozycja była wątpliwa [14]. Pomimo szerokich możliwości zapobiegania ekspozycji zawodowej nie da się jej całkowicie wyeliminować [15]. W przypadku ekspozycji na materiał potencjalnie zakaźny pracownik powinien jak najszybciej wdrożyć postępowanie poekspozycyjne. Podjęte działania mają na celu redukcję ryzyka zakażenia drobnoustrojem chorobotwórczym [18]. Według badań przeprowadzonych przez Dyk-Duszyńską znajomość procedury poekspozycyjnej deklarują prawie wszystkie pielęgniarki (90,42\%). Badania własne wykazały, że wiedza na temat postępowania poekspozycyjnego pielęgniarek operacyjnych jest na wysokim poziomie. Pielęgniarki te bowiem ogółem udzielały średnio 14,41 prawidłowych odpowiedzi na 18 pytań w przeprowadzonym teście co stanowi $80,6 \%$. Bezpośrednio po ekspozycji jak najszybciej należy wdrożyć postępowanie nieswoiste, które jest uzależnione od rodzaju ekspozycji
[15]. Pielęgniarki operacyjne w tym przypadku wykazały bardzo wysoki poziom wiedzy. Niemalże każda instrumentariuszka wie jakie działania podjąć w przypadku zachlapania błon śluzowych bądź śluzówek gałek ocznych (99\%). Prawie wszystkie badane wiedzą także jak postąpić w przypadku naruszenia ciągłości tkanek w wyniku: zakłucia, skaleczenia, zadrapania narzędziem medycznym skażonym krwią (92\%) oraz przedostania krwi do jamy ustnej (98\%). Nieznacznie gorzej wypadły pytania dotyczące dalszego postępowania. $86 \%$ badanych wie jakie badania wykonuje się u osoby eksponowanej. $88 \%$ pielęgniarek wiedziało kiedy wykonuje się badanie poziomu przeciwciał anty-HCV, natomiast tylko $46 \%$ wie, że testy na obecność przeciwciał anty-HIV wykonuje się bezpośrednio po ekspozycji a następnie okresowo przez kolejne 6 miesięcy (np. po 6 tygodniach, kolejno po 12 tygodniach i ostatnie po 6 miesiącach).

Pielęgniarki pracujące na bloku operacyjnym posiadają zróżnicowane wykształcenie. Jednak analiza statystyczna wykazała, że nie wpływa to na ich poziom wiedzy na temat postępowania poekspozycyjnego. Doświadczenie, odbycie podczas okresu adaptacyjnego na bloku operacyjnym szkolenia dotyczącego przestrzegania procedur epidemiologicznych, praca na stanowisku, w którym jest wdrożona i przestrzegana procedura dotycząca ekspozycji zawodowej również nie mają znaczenia. Istotnie statystyczne jedynie wiek różnicuje pielęgniarki operacyjne. Te młodsze wykazały nieznacznie wyższy poziom wiedzy. Z badań Garus-Pakowskiej i Szatko wynika także, że częściej do incydentów ekspozycji dochodzi u pielęgniarek z większym doświadczeniem [16].

Uważa się, że zasadnicze znaczenie w zakresie poprawy bezpieczeństwa pracy personelu służby zdrowia w kontakcie z krwią i innym potencjalnie zakaźnym materiałem ma prawidłowo prowadzona wieloaspektowa edukacja, której zakres powinien obejmować m.in. takie zagadnienia, jak: właściwe zasady postępowania ze sprzętem medycznym, z odpadami medycznymi, szkolenia w zakresie standardów profilaktyki poekspozycyjnej, w zakresie stosowania ochron osobistych, a także wymaganych szczepień ochronnych dla personelu a także opracowanie programów edukacyjnych dla pracowników medycznych [17].

\section{PODSUMOWANIE}

Pracownicy sektora medycznego są z racji wykonywanego zawodu grupą szczególnego ryzyka zakażenia dlatego też w Polsce zostały wprowadzone szczegółowe regulacje prawne, określające obowiązki pracodawców sektora ochrony zdrowia w zakresie bezpieczeństwa i higieny pracy przy wykonywaniu prac związanych z narażeniem na zranienie ostrymi narzędziami używanymi przy udzielaniu świadczeń zdrowotnych. Zasadne wydaje się stałe uzupełnianie wiedzy personelu medycznego w tym zakresie.

\section{ORCID}

Katarzyna Tomaszewska (D) 0000-0002-2129-9107 
Katarzyna Tomaszewska, Aleksandra Szpila

\section{REFERENCES/PIŚMIENNICTWO}

1. Szczeniowski A, Gańczak M. Implementacja przepisów regulujących zapobieganie ekspozycji zawodowej na patogeny krwiopochodne z perspektywy Polski jako kraju Unii Europejskiej. Medycyna Pracy. 2011; 62(1): 57-66.

2. Kilańska D, Trzcińska A. Ekspozycja zawodowa w praktyce. Warszawa: Wydawnictwo lekarskie PZWL; 2014, s.107.

3. Karczewski JK. (red.) Higiena. Podręcznik dla studentów pielęgniarstwa. Lublin: Wyd. Czelej; 2002, s.161-162.

4. Bilski B, Wysocki J. Analiza wiedzy pielęgniarek w zakresie profilaktyki poekspozycyjnej zakażeń krwiopochodnych na stanowisku pracy. Medycyna Pracy. 2005; 56(5): 375-378.

5. Dziedzic A. Ekspozycja zawodowa pracowników na krew. BHP Porady. wrzesieńpaździernik 2012; 3:2

6. Marcinkowski T. (red.). Higiena profilaktyka i organizacja w zawodach medycznych, Warszawa: Wydawnictwo lekarskie PZWL; 2003, s.244.

7. Rybacki M, Piekarska A. (red.). Zapobieganie zakażeniom krwiopochodnym u personelu medycznego. Łódź: Oficyna Wydawnicza Instytutu Medycyny Pracy im. prof. J. Nofera; 2012, s.41-43.

8. Paszkowska M. Instrumenty prawne zapobiegania zranieniom pracowników wpodmiotachleczniczych,http://www.bhp.abc.com.pl/czytaj/-/artykul/instrumentyprawne-zapobiegania-zranieniom-pracownikow-w-podmiotach-leczniczych, dostęp marzec 2018

9. Kozajda A, Szadkowska-Stańczyk I. Ochrona pracowników medycznych Laboratoriów diagnostycznych przed narażeniem na czynniki biologiczne. Łódź: Instytut Medycyny Pracy im. prof. J. Nofera, Zakład Środowiskowych Zagrożeń Zdrowia. Medycyna Pracy. 2011;62(3):291-295.

10. Dancewicz M. Postępowanie w przypadku ekspozycji pracowników szpitala na HBV, HCV i HIV. Przegląd Epidemiologiczny. 2005, s.674.

11. Sobolewska-Pilarczyk M, Rajewski P, Rajewski P, Hinz-Brylew N. Forum Medycyny Rodzinnej. 2016;10(5):279-282.

12. Rymer W, Bieńkowski M, Mularska E. Profilaktyka poekspozycyjna po narażeniu na zakażenie HIV, HBV, HCV-rekomendacje Polskiego Towarzystwa Naukowego AIDS na 2013 r., HIV and AIDS Review. 2013; 12:119-123.

13. Szczypta A, Różańska A, Bulanda M. Analiza ekspozycji zawodowej pracowników medycznych w latach 1998-2013 na patogeny przenoszone drogą krwi na przykładzie szpitala o profilu zabiegowym. Medycyna Pracy. 2014;65(6):723-732.

14. Dyk-Duszyńska A. Ekspozycja zawodowa pracowników medycznych na wirusy zapalenia wątroby typu B (HBV) i C (HCV) oraz ludzki wirus niedoboru odporności (HIV)- rozprawa doktorska. Poznań, 2013.

15. Garus-Pakowska A, Szatko F. Ekspozycje przezskórne personelu medycznego, Medycyna Pracy. 2011;62(5):473-480.

16. Braczkowska B, Kowalska M, Beniowski M, i wsp. Zawodowa ekspozycja pracowników służb medycznych na wirus HIV w województwie śląskim. Medycyna Pracy. 2010;61(3):315-322

17. Cybula-Walczak A. Zasady postępowania po ekspozycji zawodowej na krew i inny potencjalnie zakaźny materiał mogący zawierać wirusy HBV, HCV, HIV. Zakażenia. 2008; 6: 62-65.

18. Prochota B. "Ostry temat", postępowanie w przypadku ekspozycji zawodowej. Współczesne Pielęgniarstwo i Ochrona Zdrowia. 2016; 5(1): 35-37.
Manuscript received/Praca zgłoszona do czasopisma: 12.07.2019

Manuscript accepted/Praca zaakceptowana do druku: 09.04.2020

Translation/Tłumaczenie: Robert Tomaszewski 